\title{
Heavy Metals Uptake in Maize Grains and Leaves in Different Agro Ecological Zones in Uasin Gishu County
}

\author{
Teresa Akenga ${ }^{1}$, Vincent Sudoi ${ }^{2}$, Walter Machuka1, Emmy Kerich ${ }^{2}$, Elkana Ronoh ${ }^{2}$ \\ ${ }^{1}$ Office of the Vice Chancellor, University of Eldoret, Eldoret, Kenya \\ ${ }^{2}$ School of Environmental Studies, University of Eldoret, Eldoret, Kenya \\ Email: takenga@uoeld.ac.ke,vsudoi2010@gmail.com,wamachuka@yahoo.com,emmycheptoo@gmail.com, \\ elkanaronoh@gmail.com
}

How to cite this paper: Akenga, T., Sudoi, V., Machuka, W., Kerich, E. and Ronoh, E. (2017) Heavy Metals Uptake in Maize Grains and Leaves in Different Agro Ecological Zones in Uasin Gishu County. Journal of Environmental Protection, 8, 14351444.

https://doi.org/10.4236/jep.2017.812087

Received: October 23, 2017

Accepted: November 10, 2017

Published: November 13, 2017

Copyright $\odot 2017$ by authors and Scientific Research Publishing Inc. This work is licensed under the Creative Commons Attribution International License (CC BY 4.0).

http://creativecommons.org/licenses/by/4.0/

\section{(c) (i) Open Access}

\begin{abstract}
Maize grain is the second most vital food after wheat to humans and forms an important part of a human diet due to its nutrients. In Kenya, it is estimated that one out of every two acres of land put to crop production is under maize crop. Maize can also be fed whole to livestock (grazed or chopped and ensiled). Due to increased demand and the need for higher productivity, farmers have adopted modern farming methods which include use of fertilizers, pesticides, compost manure, and irrigation. Uses of these products elevate amounts of heavy metals in the soil. Such heavy metals such as lead $(\mathrm{Pb})$ and cadmium when taken up by plants accumulate in the plants becoming toxic at high levels. It is essential to monitor these levels in grains and leaves to ensure they do not exceed the WHO permissible limits. This study aimed at monitoring the levels of heavy metals uptake in maize (Zea mays) grains and leaves is within permissible levels. Level of heavy metals in maize grains from different ecological zones in UG County had mean concentration of $\mathrm{Zn} 0.122$, Cd 0.03, $\mathrm{Cu} 0.111$, Co 0.04, and $\mathrm{Pb} 0.33 \mathrm{mg} / \mathrm{kg}$. These results were below WHO standards except for Cadmium, $\mathrm{Co}$, and $\mathrm{Pb}$ which were slightly higher than recommended standard. The study also found that maize leaves had mean con-

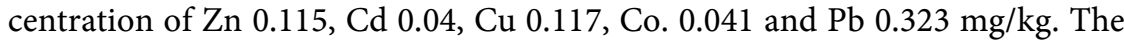
results were below $\mathrm{WHO}$ standards except $\mathrm{Co}$ and $\mathrm{Pb}$ which had slightly higher levels than the recommended WHO standards. The analytical results from this study provided important baseline statistics on the concentration of selected heavy metals in maize grains and leaves besides being an important assessment of environmental pollution in rural areas where maize farming is predominant.
\end{abstract}

\section{Keywords}

Heavy Metals, Maize Grains and Seeds, Uasin Gishu County, 
Agro-Ecological Zones

\section{Introduction}

Maize (Zea mays L.) serves as the main food source for humans and animals around the world. Approximately ninety six percent of Kenyan population consumes maize which provides $40 \%$ of the calorie necessities in Kenya [1] [2] [3]. Maize can also be used in animal feed as a feedstock source [4]. In order to meet it's ever increasing demand for both domestic consumption and for the export market, farmers are now employing different methods of farming such as application of fertilizers, pesticides, compost manure and irrigation to improve and protect the maize [5]. However, agricultural practices such application of phosphatic fertilizers; pesticides and refuse derived composts contribute to heavy metals in the soil [6] [7] [8]. Heavy metals are those elements with higher density than five milligrams per liter [8]. These metals include; arsenic (Ar), cadmium $(\mathrm{Cd})$, copper $(\mathrm{Cu})$, lead $(\mathrm{Pb})$, cobalt $(\mathrm{Co})$ and zinc $(\mathrm{Zn})$ etc. [9].

Ascertaining heavy metals in food plants is vital since human being ingest plants that could contain hazardous chemicals [10]. Heavy metal contamination through food chain could cause adverse effects to human beings and environment [11].

Bioavailability of the chemicals is determined by their bond form with the components of the soil. Plants readily take up such elements in ionic form through the roots. Consequently, the rate of metal uptake by a plant could be determined by aspects such as; the plants species, age and parts metal species and also the metal species involved [1] [12] [13]. Heavy metal even at low concentration could lead to long-term mounting health impacts [14]. Plants bio-accumulates heavy metals from the soil and when ingested by human beings and animals, the heavy metal accumulate in the body with serious health effects [15] [16].

Studies in Kenya and Nigeria revealed high levels of some heavy metals in maize and vegetable crops and maize is a worry to the consumers [17] [18]. The study in Kenya (Thika) revealed that the average levels of $\mathrm{Pb}, \mathrm{Zn}$ and $\mathrm{Cd}$ in all the studied vegetables exceeded the maximum accepted concentrations. $\mathrm{Pb}$ levels in the vegetables were documented to be $0.3 \mathrm{mg} / \mathrm{kg}$ which was above the accepted World Health Organization (WHO) standards. Therefore this study sets out to determine total heavy metal up take in maize in farms in different agro-ecological zones in UG County.

\section{Materials and Methods}

\subsection{Study Area}

Uasin Gishu (UG) County covers an approximate area of $3327.8 \mathrm{~km}^{2}$. The population of the county is about 771,536 people with a population density of 232 
per $\mathrm{km}^{2}$. Close to $218 \mathrm{~km}^{2}$ of its land is covered by hills and water. Recently the total land under farming is approximately 134,490 hectares [19]. The total number of maize farmers is roughly 166,635 [20].

\subsubsection{Weather}

The County has an altitude of $1800 \mathrm{~m}$ above sea level [21] and regular annual rainfall ranges from 900 to $1200 \mathrm{~mm}$ per year. The county experiences unimodal Rainfall with distinct peaks in April and August [22].

\subsubsection{Agricultural Activities}

The county is basically agricultural producer and produces, Maize, wheat, beans, potatoes and vegetables. The county has six sub-counties which include; Soi, Moiben, Turbo, Kapseret, Kesses and Ainabkoi. It is further divided into fifty-one locations and ninety-six sub-locations.

\subsubsection{Agro-Ecological Zones}

The county has three agro-ecological zones they include Upper Highland Zone dominated by Nitisols soils, Upper Midland Zone dominated by Acrisols and Lower Highland Zone dominated by Ferralsols with patches of Gleysols in between [23].

\subsection{Experimental Procedures}

\subsubsection{Plant Material}

Maize plant (leaf and grain) was chosen specifically because, among other cereals, it is frequently taken by resident as a stable food and they can accumulate heavy metals, especially with no noticeable intoxication symptoms, which can elevate the risk to human health.

\subsubsection{Apparatus and Instruments}

In order to analyze for presence of heavy metals in maize grain and leaf brown paper bags were used to carry the collected samples, air-circulating oven was used for drying the samples, blender ceramic mortar and pestle was used for homogenizing the ground the plant samples, digital analytical balance with \pm $0.0001 \mathrm{~g}$ precision was used to weigh samples, and digestion tubes were employed for digesting sample. Aluminum block digester was used as heating apparatus during sample digestion. Volumetric flasks of differing volumes (Pyrex, USA) were used during dilution and preparation of metal standards. Micropipettes, Measuring cylinders, burettes and pipettes (Pyrex, USA) was used to measure volumes of sample solution, acid reagents and metal standard solutions.

\subsubsection{Chemicals and Reagents}

Analytical grade chemicals and reagents were used in the analysis. $69 \%-72 \%$ $\mathrm{HNO}_{3}$ and $70 \% \mathrm{HClO}_{4}$ for the digestion of the selected maize plant grains, To avoid chemical intrusion on $\mathrm{Ca}$ determination during the analysis of the plant samples, Lanthanum nitrate hydrate (98\% Aldrich, USA) solution was used. 99\% $\mathrm{KCl}$ solution was used as suppressor of chemical interference on analysis of 
chromium from plant. Stock standard solutions of $1000 \mathrm{mg} / \mathrm{kg}$ concentration of the essential and toxic heavy metals from which $100 \mathrm{Mg} / \mathrm{kg}$ intermediate standards obtained was used for the preparation of the calibration standards of each metal. During sample preparation, dilution, and rinsing apparatus prior to analysis, deionized water was used.

\subsubsection{Cleaning Apparatus}

Deionized water was used to clean and rinse apparatus such as glassware, plastic containers and polyethylene bags. The apparatus was then soaked in about $10 \%$ volume to volume nitric acid for 24 hours followed by rinsing with deionized water several times. Then, the apparatus was dried in oven and kept in dust free place until further use.

\subsubsection{Sample Collection and Preparation}

The maize grains samples were de-husked into grains while one leaf was picked in five plants in each selected sites randomly. The leaves and grains were stored in clean khaki bags. 5.0 gramms of the samples from each location were measured into different containers. The samples from each of the containers were dried in a hot air circulating oven at 70 degrees centigrade (Gallenkemp DV 330) for 18 - 24 hours. The dried samples from the different containers were mixed together and homogenized with a mixer grinded to powder. Ground plant samples were then collected in labeled polythene bags and were placed in a desiccators awaiting laboratory analysis [24] [25] [26].

\subsubsection{Sample Analysis}

One gram of dried plant leaf and grain samples were weighed and placed in digestion tubes. Four $\mathrm{mL}$ of freshly prepared 2:2 (v/v) mixture of $70 \%$ of conc. $\mathrm{HNO}_{3}$ and $70 \%$ of conc. $\mathrm{HClO}_{4}$ was added to the plant samples. Five ml of freshly prepared 3:2 (v/v) mixture of 70 percent of concentrated $\mathrm{HNO}_{3}$ and 70 percent of concentrated. $\mathrm{HClO}_{4}$ was added to maize grains powders. The mixtures were then digested on block digester at $270^{\circ} \mathrm{C}$ for 150 minutes. The digested solutions were allowed to cool for 30 minutes. After that, the digested sample was solubilized with 5 milliliters of aqua regia [27]. The digest was then cooled and filtered through whatman No 1 filter paper into $50 \mathrm{ml}$ volumetric flask and diluted to $50 \mathrm{ml}$ mark with distilled water according to procedure reported by [28]. A blank was prepared with an equal amount of acids. All reagents were of analytical grade and contained very low concentrations of trace metals. For each bulk samples, triplicate digestions were carried out. The digested and diluted sample solution was stored in volumetric flask and was kept in refrigerator until analysis time [29]. Normal precautions for trace metals analysis was observed throughout. The $\mathrm{Pb}, \mathrm{Cd}, \mathrm{Co} \mathrm{Zn}$ and $\mathrm{Cu}$ concentrations was determined using Inductive couple plasma (Perkin-Elmer OPTIMA-2000, USA).

\subsection{Statistical Analysis}

Mean values obtained for $\mathrm{Zn}, \mathrm{Cu}, \mathrm{Pb}, \mathrm{Cd}$ and $\mathrm{Co}$ from the three regions was 
compared by One-Way ANOVA at 95\% level using SPSS 18 for windows, T-test was used to compare levels of heavy metals from maize grains and leaves.

\section{Results}

\subsection{Comparisons between Grains, Leaves and Agro-Ecological Zone}

To determine whether there was a significant difference in the levels of heavy metals in maize grain in three ecological zones of UG County One-Way ANOVA was conducted. Table 1 below shows heavy metal levels and ANOVA results in maize grains from 3 sites in UG County.

Table 1. ANOVA results of heavy metal levels in maize grains from three sites in Uasin Gishu.

\begin{tabular}{ccccccc}
\hline & $\begin{array}{c}\text { Turbo } \\
\text { Mean } \\
\text { value }(\mathrm{mg} / \mathrm{kg})\end{array}$ & $\begin{array}{c}\text { Moiben } \\
\text { Mean } \\
\text { value }(\mathrm{mg} / \mathrm{kg})\end{array}$ & $\begin{array}{c}\text { Burnt Forest } \\
\text { Mean } \\
\text { value }(\mathrm{mg} / \mathrm{kg})\end{array}$ & Df & F & P \\
\hline $\mathrm{Zn}$ & 0.088 & 0.144 & 0.135 & 17 & 4.381 & 0.032 \\
$\mathrm{Cd}$ & 0.080 & 0.009 & 0.011 & 17 & 1.395 & 0.278 \\
$\mathrm{Cu}$ & 0.095 & 0.120 & 0.119 & 17 & 1.624 & 0.230 \\
$\mathrm{Co}$ & 0.037 & 0.040 & 0.045 & 17 & 0.969 & 0.402 \\
$\mathrm{~Pb}$ & 0.285 & 0.382 & 0.348 & 17 & 0.947 & 0.410 \\
\hline
\end{tabular}

According to $\mathrm{t}$ test results above, the $\mathrm{p}$ values of $\mathrm{Zn}$ at different ecological zones was 0.032 below the 0.05 significance level indication significance at $95 \%$. The $\mathrm{p}$ values of $\mathrm{Cd}, \mathrm{Cu}, \mathrm{Co}$ and $\mathrm{Pb}$ were $0.278,0.230,0.402$, and 0.410 respectively. They were above 0.05 significance level indicating there was no significance at $95 \%$ in content of heavy metals in grains from the different ecological zones of UG County.

\subsection{Concentration of Heavy Metals in Leaves}

To determine whether there existed significant differences in the levels of heavy metals in maize leaves in three Agro-ecological zones in UG County, One-Way ANOVA was conducted. The results are presented in Table 2 below.

Table 2. ANOVA results of heavy metals in maize leaves from three sites in Uasin Gishu county.

\begin{tabular}{ccccccc}
\hline & $\begin{array}{c}\text { Turbo } \\
\text { Mean value } \\
(\mathrm{mg} / \mathrm{kg})\end{array}$ & $\begin{array}{c}\text { Moiben } \\
\text { Mean value } \\
(\mathrm{mg} / \mathrm{kg})\end{array}$ & $\begin{array}{c}\text { Burnt Forest } \\
\text { Mean value } \\
(\mathrm{mg} / \mathrm{kg})\end{array}$ & $\mathrm{df}$ & $\mathrm{F}$ & $\mathbf{P}$ \\
\hline $\mathrm{Zn}$ & 0.108 & 0.125 & 0.113 & 17 & 2.120 & 0.155 \\
$\mathrm{Cd}$ & 0.108 & 0.010 & 0.013 & 17 & 1.364 & 0.286 \\
$\mathrm{Cu}$ & 0.116 & 0.117 & 0.119 & 17 & 1.204 & 0.327 \\
$\mathrm{Co}$ & 0.040 & 0.040 & 0.043 & 17 & 10.000 & 0.002 \\
$\mathrm{~Pb}$ & 0.318 & 0.315 & 0.336 & 17 & 7.252 & 0.006 \\
\hline
\end{tabular}


According to $\mathrm{t}$ test results above, the $\mathrm{p}$ values of $\mathrm{Co}$ and $\mathrm{Pb}$ was 0.002 and 0.006 respectively below the 0.05 significance level at $95 \%$. The $\mathrm{p}$ values of $\mathrm{Zn}$, $\mathrm{Cd}$, and $\mathrm{Pb}$ were $0.155,0.286$, and 0.327 respectively. They were above 0.05 significance level indicating there was no significance at $95 \%$ in the content of heavy metals in leaves at different ecological zones in UG County.

\subsection{Levels of Heavy Metals in Grain and Leaves}

To determine whether there existed significant differences in the levels of heavy metals in maize grain and leaves in three sampling site in Uasin Gishu Agroecological zones, T-test was conducted. The results are presented in Table 3.

Table 3. T test results comparing level of heavy metals in maize grains and leaves in Uasin Gishu county.

\begin{tabular}{|c|c|c|c|c|c|c|}
\hline & $\begin{array}{c}\text { Grains } \\
\text { Mean value }\end{array}$ & $\begin{array}{c}\text { Leaves } \\
\text { Mean value }\end{array}$ & $t$ & $\mathrm{DF}$ & $\begin{array}{c}\text { Significance } \\
\text { (2-tailed) }\end{array}$ & $\begin{array}{c}\text { Mean } \\
\text { Difference }\end{array}$ \\
\hline $\mathrm{Zn}$ & 0.122 & 0.115 & 0.655 & 34 & 0.517 & 1.389 \\
\hline $\mathrm{Cd}$ & 0.009 & 0.011 & 1.506 & 34 & 0.141 & 0.333 \\
\hline $\mathrm{Cu}$ & 0.111 & 0.117 & 0.867 & 34 & 0.392 & 1.167 \\
\hline Co & 0.041 & 0.041 & 0.222 & 34 & 0.826 & 0.111 \\
\hline $\mathrm{Pb}$ & 0.321 & 0.323 & 0.129 & 34 & 0.898 & 0.500 \\
\hline
\end{tabular}

According to t test results above, the $\mathrm{P}$ values of $\mathrm{Zn}, \mathrm{Cd}, \mathrm{Cu}, \mathrm{Co}$ and $\mathrm{Pb}$ were $0.517,0.141,0.392,0.826$ and 0.898 respectively. They were above 0.05 significance level indicating there was no significance at $95 \%$ in the content of heavy metals in leaves and grains in UG County.

\subsection{Comparison of Heavy Metals in Grains and Leaves with WHO/FAO Standards}

Table 4 below shows $\mathrm{Zn}$ and $\mathrm{Cu}$, were below the recommended FAO standards and posed no risk to the consumers of grains. However $\mathrm{Cd}, \mathrm{Co}$ and $\mathrm{Pb}$ were slightly above the WHO/FAO standards.

Table 4. Mean heavy metals in maize grains and leaves in UG county and the maximum recommended concentration in food crops (FAO/WHO, 2001).

\begin{tabular}{cccc}
\hline Heavy metal & $\begin{array}{c}\text { Mean (Grain) for } \\
\text { three sites (mg/kg) }\end{array}$ & $\begin{array}{c}\text { Mean (Leave) for three } \\
\text { sites (mg/kg) }\end{array}$ & $\begin{array}{c}\text { WHO } \\
\text { standards }(\mathrm{mg} / \mathrm{kg})\end{array}$ \\
\hline $\mathrm{Zn}$ & 0.122 & 0.115 & 3 \\
$\mathrm{Cd}$ & 0.033 & 0.043 & 0.03 \\
$\mathrm{Cu}$ & 0.111 & 0.117 & 2 \\
$\mathrm{Co}$ & 0.04 & 0.041 & 0.01 \\
$\mathrm{~Pb}$ & 0.338 & 0.323 & 0.1 \\
\hline
\end{tabular}




\section{Discussion}

\subsection{Heavy Metal Content in Maize Grains and Leaves in Uasin Gishu County}

\subsubsection{Maize Grains}

The mean levels of heavy metals in maize grain in the three ecological zones of UG county varied significantly $(\mathrm{P}<0.05)$. Only $\mathrm{Zn}$ concentration varied significantly while $\mathrm{Pb}, \mathrm{Cd}, \mathrm{Co}$, and $\mathrm{Cu}$ did not vary significantly (Table 1 ). The concentrations of heavy metals of $\mathrm{Pb}$ and $\mathrm{Cd}$, in maize grains in this study were above the permissible limits recommended by FAO/WHO. Although Zn concentration varied significantly in the three ecological zones it did not exceed those recommended by WHO. Similar studies in Kaduna Nigeria [30] found the heavy metal concentration to be higher in maize grain (Concentration of Copper $(\mathrm{Cu})$ in the maize grain samples analyzed was $0.98 \mathrm{mg} / \mathrm{kg}$ and that of $\mathrm{Zn}$ was $2.01 \mathrm{mg} / \mathrm{kg}$ ).

\subsubsection{Maize Leaves}

The concentration of $\mathrm{Co}$ and $\mathrm{Pb}$ varied significantly $(\mathrm{P}<0.05)$ in leaves from the different ecological zones (Table 2). In Kenya a study on evaluation of heavy metals levels in urban grown vegetables in Thika town Kenya [17] revealed that the mean levels of $\mathrm{Pb}, \mathrm{Zn}$ and $\mathrm{Cd}$ in all the vegetables studied exceeded the WHO standards. $\mathrm{Pb}$ levels in the vegetables were reported to exceed the World Health Organization (WHO recommended limits of $0.3 \mathrm{mg} / \mathrm{kg}$. Also a study done by [31] on selected plants growing along Nairobi River for accumulation of $\mathrm{Cu}, \mathrm{Zn}$ and $\mathrm{Cd}$, indicated that the levels of the heavy metals in the leafy vegetables had moderately elevated levels and transfer factors of heavy metals

Elsewhere evaluation of heavy metals in Grain Fields with Long-term treatment of agrochemicals and organic manure e.g. in Hailun City of Northeast China revealed a occurrence of considerably elevated concentrations of zinc, copper and lead in organic manure combined with chemical fertilizer in the grain fields of black soils [32]. Nevertheless [33] in a greenhouse experiment with maize seeds (Zea mays L.) and heavy metals distribution in maize plants (Zea mays L.) observed the highest metal levels in roots. Important differences were found for aerial plant parts as regards metal buildup, whereas metal levels in grains were insignificant in all the treatments. Therefore, factors such as plant species, metal species and soil features determine accumulation and distribution of heavy metals in plants [34] [35].

A number of studies [14] [36] have shown that heavy metal ingestion through food results in continuous low concentration body accrual of heavy metals and the negative impact becomes evident only after numerous years of exposure.

\section{Conclusions and Recommendation}

Maize grain and leaves samples from the five regions were found to contain $\mathrm{Pb}$, $\mathrm{Cd}, \mathrm{Zn}, \mathrm{Cu}$, and $\mathrm{Co}$. There were significant variations in levels of $\mathrm{Zn}, \mathrm{Pb}$, and $\mathrm{Cd}$ 
in grains and leaves from the three regions. Concentrations of $\mathrm{Pb}$ and $\mathrm{Cd}$ in both maize grains and leaves were above the permissible limits recommended by $\mathrm{FAO} / \mathrm{WHO}$.

Therefore, monitoring of heavy metals in food crops should be regular done so as to avert too much buildup of these heavy metals in body.

\section{References}

[1] Dowswell, C.R., Paliwal, R.L. and Cantrell, R.P. (1996) Maize in the Third World. Westview Press, Boulder.

[2] Beesley, L., Moreno-Jiménez, E. and Gomez-Eyles, J.L. (2010) Effects of Biochar and Greenwaste Compost Amendments on Mobility, Bioavailability and Toxicity of Inorganic and Organic Contaminants in a Multi-Element Polluted Soil. Environmental Pollution, 158, 2282-2287. https://doi.org/10.1016/j.envpol.2010.02.003

[3] Omoyo, N.N., Wakhungu, J. and Oteng'i, S. (2015) Effects of Climate Variability on Maize Yield in the Arid and Semi Arid Lands of Lower Eastern Kenya. Agriculture \& Food Security, 4, 8.

[4] Jompuk, C., Cheuchart, P., Jompuk, P. and Apisitwanich, S. (2011) Improved Tryptophan Content in Maize with Opaque-2 Gene Using Marker Assisted Selection (MAS) in Backcross and Selfing Generations. Kasetsart Journal (Natural Science), 45, 666-674.

[5] Ibrahim, K.N., Yet, Z.R., Som, A.M., Razali, N., Rahaizah, N.A.M., Othman, E.N., Yahya, T.F.T., et al. (2015) The Heavy Metal Concentration ( $\mathrm{Pb}, \mathrm{Cu}, \mathrm{Fe}, \mathrm{Zn}, \mathrm{Ni}$ ) in Plant Parts of Zea mays L. Cultivated in Agricultural Area Near Alor Gajah, Melaka, Malaysia. American Journal of Environmental Engineering, 5, 8-12.

[6] Bolan, N.S. and Duraisamy, V.P. (2003) Role of Inorganic and Organic Soil Amendments on Immobilisation and Phytoavailability of Heavy Metals: A Review Involving Specific Case Studies. Soil Research, 41, 533-555. https://doi.org/10.1071/SR02122

[7] Nicholson, F.A., Smith, S.R., Alloway, B.J., Carlton-Smith, C. and Chambers, B.J. (2003) An Inventory of Heavy Metals Inputs to Agricultural Soils in England and Wales. Science of the Total Environment, 311, 205-219.

[8] Järup, L. (2003) Hazards of Heavy Metal Contamination. British Medical Bulletin, 68, 167-182. https://doi.org/10.1093/bmb/ldg032

[9] Khanna, P. (2011) Assessment of Heavy Metal Contamination in Different Vegetables Grown in and around Urban Areas. Research Journal of Environmental Toxicology, 5, 162. https://doi.org/10.3923/rjet.2011.162.179

[10] Nasreddine, L. and Parent-Massin, D. (2002) Food Contamination by Metals and Pesticides in the European Union. Should We Worry? Toxicology Letters, 127, 29-41.

[11] McLaughlin, M.J., Zarcinas, B.A., Stevens, D.P. and Cook, N. (2000) Soil Testing for Heavy Metals. Communications in Soil Science \& Plant Analysis, 31, 1661-1700. https://doi.org/10.1080/00103620009370531

[12] Amusan, A.A., Ige, D.V. and Olawale, R. (2005) Characteristics of Soils and Crops' Uptake of Metals in Municipal Waste Dump Sites in Nigeria. Journal of Human Ecology, 17, 167-171.

[13] Singh, A., Sharma, R.K., Agrawal, M. and Marshall, F.M. (2010) Health Risk Assessment of Heavy Metals via Dietary Intake of Foodstuffs from the Wastewater Irrigated Site of a Dry Tropical Area of India. Food and Chemical Toxicology, 48, 
611-619.

[14] Oluyemi, E.A., Feuyit, G., Oyekunle, J.A.O. and Ogunfowokan, A.O. (2008) Seasonal Variations in Heavy Metal Concentrations in Soil and Some Selected Crops at a Landfill in Nigeria. African Journal of Environmental Science and Technology, 2, 89-96.

[15] John, Y.A.B.E., Ishizuka, M. and Umemura, T. (2010) Current Levels of Heavy Metal Pollution in Africa. Journal of Veterinary Medical Science, 72, 1257-1263. https://doi.org/10.1292/jvms.10-0058

[16] USEPA (2002) Solid Waste and Emergency Response. AGENCY, USEPA.

[17] Malomo, O., Olufade, O.I., Adekoyeni, O.O. and Jimoh, M.O. (2013) Evaluation of Heavy Metal Concentration in Maize Grown in Selected Industrial Areas of Ogun State and Its Effects on Urban Food Security. International Journal of Science, Technology and Society, 1, 48-56. https://doi.org/10.11648/j.ijsts.20130102.12

[18] Inoti, K.J., Fanuel, K., George, O. and Paul, O. (2012) Assessment of Heavy Metal Concentrations in Urban Grown Vegetables in Thika Town, Kenya. African Journal of Food Science, 6, 41-46.

[19] Baraza, D.S.E., Chepkwony and Githae, T. (2008) Kenya Food Security Steering Group. Long Rains Rapid Food in the Arid and Semi Arid Lands of Lower Eastern Kenya. Agriculture \& Food Security, 4, 8.

[20] Wanjala, J.K. (2014) Factors Affecting Maize Farmers' Participation in Agricultural Extension Education: A Comparison of Farmers in Turkana and Uasin-Gishu Counties, Kenya.

[21] Lwayo, M.K., Okalebo, J.R., Muasya, R.M. and Mongare, P.O. (2001) A Diagnostic Survey on the Production Constraints and Utilization of Phosphate Fortified Wheat Straw and Maize Stover Compost for Increasing Cereal Production in Uasin Gishu District, Kenya. A Report, 108.

[22] Kibet, N., Lagat, J. and Obare, G. (2011) Identifying Efficient and Profitable Farm Enterpise in Uasin Gishu County in Kenya. Asian Journal of Agricultural Research, 37, 378-384.

[23] Jaetzold, R. and Schmidt, H. (1983) Farm Management of Kenya. Vol. II C. East Kenya.

[24] Maimon, T., Elad, N., Dahan, I. and Medalia, O. (2012) The Human Nuclear Pore Complex as Revealed by Cryo-Electron Tomography. Structure, 20, 998-1006.

[25] Faithfull, N.T. (2002) Methods in Agricultural Chemical Analysis: A Practical Handbook. CABI. https://doi.org/10.1079/9780851996080.0000

[26] Ebong, P.E., Atangwho, I.J., Eyong, E.U. and Egbung, G.E. (2008) The Antidiabetic Efficacy of Combined Extracts from Two Continental Plants: Azadirachtaindica (A. Juss)(Neem) and Vernoniaamygdalina (Del.)(African Bitter Leaf). American Journal of Biochemistry and Biotechnology, 4, 239-244.

https://doi.org/10.3844/ajbbsp.2008.239.244

[27] Chen, J., Hamon, M.A., Hu, H., Chen, Y., Rao, A.M., Eklund, P.C. and Haddon, R.C. (1998) Solution Properties of Single-Walled Carbon Nanotubes. Science, 282, 95-98. https://doi.org/10.1126/science.282.5386.95

[28] Onyedika, G.O. and Nwosu, G.U. (2008) Lead, Zinc and Cadmium in Root Crops from Mineralized Galena-Sphalerite Mining Areas and Environment. Pakistan Journal of Nutrition, 7, 418-420. https://doi.org/10.3923/pjn.2008.418.420

[29] Aga, M.A. and Haramaya, E. (2012) Determination of Selected Metals in Grainss, Flowers and Fruits of Some Medicinal Plants Used for Treatment of Tapeworm. 
[30] Sulyman, Y.I., Abdulrazak, S., Oniwapele, Y.A. and Amad, A. (2015) Concentration of Heavy Metals in Some Selected Cereals Sourced within Kaduna State, Nigeria. Journal of Environmental Science, Toxicology and Food Technology, 9, 17-19.

[31] Owiti, O.T. (2015) Assessment of Selected Plants Growing along Nairobi River for Uptake of Copper, Zinc and Cadmium, Nairobi County, Kenya (Doctoral Dissertation).

[32] Zakir, S., Shang, Z., Xu, Y., Zhan, L. and Li, C. (2011) Assessment of Heavy Metals in Grain Fields with Long-Term Treatment of Agrochemicals and Organic Manure in Hailun City of Northeast China. Journal of Northeast Agricultural University (English Edition), 18, 30-35.

[33] Carbonell, G., de Imperial, R.M., Torrijos, M., Delgado, M. and Rodriguez, J.A. (2011) Effects of Municipal Solid Waste Compost and Mineral Fertilizer Amendments on Soil Properties and Heavy Metals Distribution in Maize Plants (Zea mays L.). Chemosphere, 85, 1614-1623.

[34] Yoon, J., Cao, X., Zhou, Q. and Ma, L.Q. (2006) Accumulation of Pb, Cu, and $\mathrm{Zn}$ in Native Plants Growing on a Contaminated Florida Site. Science of the Total Environment, 368, 456-464.

[35] Nouri, J., Khorasani, N., Lorestani, B., Karami, M., Hassani, A.H. and Yousefi, N. (2009) Accumulation of Heavy Metals in Soil and Uptake by Plant Species with Phytoremediation Potential. Environmental Earth Sciences, 59, 315-323. https://doi.org/10.1007/s12665-009-0028-2

[36] Oluyemi, E.A., Feuyit, G., Oyekunle, J.A.O. and Ogunfowokan, A.O. (2008) Seasonal Variations in Heavy Metal Concentrations in Soil and Some Selected Crops at a Landfill in Nigeria. African Journal of Environmental Science and Technology, 2, $89-96$. 